GRASAS Y ACEITES, 63 (1),

ENERO-MARZO, 35-43, 2012,

ISSN: 0017-3495

DOI: $10.3989 /$ gya.06891

\title{
Comparative study of the methanolysis and ethanolysis of maize oils using alkaline catalysts
}

\author{
By U. Rashid ${ }^{1,2^{*}}$, M. Ibrahim ${ }^{3,4}$, S. Ali ${ }^{3}$, M. Adii ${ }^{3}$, S. Hina ${ }^{3}$, I.H. Bukhari ${ }^{5}$ and R. Yunus ${ }^{1}$ \\ ${ }^{1}$ Institute of Advanced Technology, Universiti Putra Malaysia, 43400 UPM Serdang, Selangor, Malaysia \\ ${ }^{2}$ Department of Industrial Chemistry, Government College University, Faisalabad-38000, Pakistan \\ ${ }^{3}$ Department of Environmental Sciences, Government College University, Faisalabad-38000, Pakistan \\ ${ }^{4}$ Department of Agricultural Environment, National Academy of Agricultural Science, Rural Development \\ Administration, Suwon 441-707, South Korea \\ ${ }^{5}$ Department of Chemistry, Government College University, Faisalabad-38000, Pakistan \\ ${ }^{\star}$ Corresponding author: dr.umer.rashid@ gmail.com
}

\section{RESUMEN}

Estudio comparativo de metanolisis y etanolisis de aceites de maíz utilizando catalizadores alcalinos

Con el aumento de la población y el desarrollo económico, el combustible y los recursos renovables deben ser explorados ampliamente con el fin de satisfacer la demanda futura de energía. En el presente estudio, se evaluó el biodiesel formado a partir de aceite de maíz mediante reacciones de transesterificación con metanol y el etanol, en presencia de $\mathrm{NaOCH}_{3}, \mathrm{KOCH}_{3}$, $\mathrm{NaOCH}_{2} \mathrm{CH}_{3}, \mathrm{KOCH}_{2} \mathrm{CH}_{3}, \mathrm{NaOH}$ y KOH como catalizadores. Se determinó la influencia de las variables de reacción, como la relación molar alcohol / aceite (03:01$15: 01)$, la concentración de catalizador (0.25 a $1.50 \%$ ) y el tiempo de reacción (20-120 min) para lograr el máximo rendimiento a temperaturas de reacción fija. Las variables optimizadas en el caso de metanólisis, 6:1 metanol/aceite relación molar $(\mathrm{mol} / \mathrm{mol}), 0,75 \%$ de metilato sódico (wt\%) y $90 \mathrm{~min}$ de tiempo de reacción a $65^{\circ} \mathrm{C}$, dieron un rendimiento de ésteres metílicos del $97,1 \%$. Mientras que una relación molar 9:1 etanol/aceite (mol/ $\mathrm{mol}$ ), $1,0 \%$ de etóxido de sodio (wt\%) y $120 \mathrm{~min}$ de reacción a $75^{\circ} \mathrm{C}$ ofrecen un rendimiento máximo de hasta un $85 \%$ para los ésteres etílicos. La reacción de metanólisis del aceite de maíz fue más rápida en comparación con la etanolisis. El análisis mediante cromatografia de gases del biodiesel producido a partir del aceite de maíz mostraron altos niveles de ácido linoleico (hasta 50,89\%) seguido de oleico (hasta $36,00 \%$ ), palmítico (hasta 9,98\%), esteárico (hasta 1,80\%) y linolénico (hasta $0,98 \%$ ). Los ésteres obtenidos fueron analizados mediante transformada de Fourier (FTIR) para garantizar la realización de transesterificación. Se han determinado las propiedades combustibles del biodiesel producido; es decir, viscosidad cinemática, número de cetano, estabilidad oxidativa, punto de fluidez, punto de turbidez, punto de obstrucción del filtro frío, contenido de cenizas, punto de inflamación, índice de acidez, contenido de azufre, poder calorífico, densidad, contenido de metanol, glicerol libre y esterificado. Los análisis se realizaron mediante FTIR y los resultados se compararon con las normas ASTM y EN para biodiesel.

PALABRAS CLAVE: Aceite de semilla de maíz - Catalizadores alcalinos - Etanolisis - Metanolisis - Propiedades de los Combustibles.

\section{SUMMARY}

Comparative study of the methanolysis and ethanolysis of Maize oil using alkaline catalysts

With an increasing population and economic development, fuel from renewable resources needs to be widely explored in order to fulfill the future energy demand. In the present study, biodiesel from maize oil using transesterification reactions with methanol and ethanol was evaluated in the presence of $\mathrm{NaOCH}_{3}, \mathrm{KOCH}_{3}, \mathrm{NaOCH}_{2} \mathrm{CH}_{3}, \mathrm{KOCH}_{2} \mathrm{CH}_{3}$, $\mathrm{NaOH}$ and $\mathrm{KOH}$ as catalysts. The influence of reaction variables such as the alcohol to oil molar ratio (3:1-15:1), catalyst concentration (0.25-1.50\%) and reaction time (20-120 $\mathrm{min}$ ) to achieve the maximum yield was determined at fixed reaction temperatures. The optimized variables in the case of methanolysis were 6:1 methanol to oil molar ratio (mol/ $\mathrm{mol}$ ), $0.75 \%$ sodium methoxide concentration (wt\%) and 90 min reaction time at $65^{\circ} \mathrm{C}$, which produced a yield of $97.1 \%$ methyl esters. A 9:1 ethanol to oil molar ratio $(\mathrm{mol} / \mathrm{mol})$, $1.00 \%$ sodium ethoxide concentration (wt\%) and $120 \mathrm{~min}$ reaction time at $75^{\circ} \mathrm{C}$ were found to produce the maximum ethyl ester yield of up to $85 \%$. The methanolysis of maize oil was depicted more rapidly as compared to the ethanolysis of maize oil. Gas chromatography of the produced biodiesel from maize oil showed high levels of linoleic acid (up to $50.89 \%$ ) followed by oleic acid (up to $36.00 \%$ ), palmitic acid (up to $9.98 \%$ ), oleic acid (up to $1.80 \%$ ) and linolenic acid (up to $0.98 \%$ ). The obtained fatty acid esters were further analyzed by fourier transform infrared spectroscopy (FTIR) to ensure the completion of transesterification. The fuel properties of the produced biodiesels i.e. kinematic viscosity, cetane number, oxidative stability, pour point, cloud point, cold filter plugging point, ash content, flash point, acid value, sulfur content, higher heating value, density, methanol content, free glycerol and bound glycerol were determined. The analyses were performed using the FTIR method and the results were compared to the biodiesel standards ASTM and EN.

KEY-WORDS: Alkaline catalysts - Ethanolysis - Fuel properties - Maize seed oil - Methanolysis.

\section{INTRODUCTION}

The world's petroleum resources are being depleted rapidly due to industrialization and a rapid 
increase in population. This depletion has not only economic concerns but also a drastic impact on the environment. This has necessitated a search for alternative resources for fossil fuels. The recent developments and advancements in the field of climate change have also resulted in the revised and renewed interest in the use of alternative sources of energy and fuel such as biodiesel, for example, from renewable resources (Anwar et al., 2010). Pakistan is facing an acute shortage of energy as are many developing countries of the region (Rashid et al., 2009). This energy crisis may be overcome by the exploitation of other energy sources. Pakistan is looking at alternative fuel sources to reduce its dependence on petroleum oil.

The most developed process using transesterification reactions employs an alkali-catalysis system with the production of a high yield (Cerveró et al., 2008). Encinar et al. (2005) described transesterification as a chemical reaction between fats and vegetable oils with alcohols to produce fatty acid methyl and ethyl esters. Glycerin, a byproduct produced in these reactions has its applications in the pharmaceutical and cosmetic industries (Rivera et al., 2009). It is a multiple reaction including three reversible steps in series as follows:

$$
\begin{aligned}
& \mathrm{TG}+\mathrm{ROH} \leftrightarrow \mathrm{DG}+\mathrm{RCO}_{2} \mathrm{R} \\
& \mathrm{DG}+\mathrm{ROH} \leftrightarrow \mathrm{MG}+\mathrm{RCO}_{2} \mathrm{R} \\
& \mathrm{MG}+\mathrm{ROH} \leftrightarrow \mathrm{GLY}+\mathrm{RCO}_{2} \mathrm{R}
\end{aligned}
$$

where TG, DG, MG, $\mathrm{RCO}_{2} \mathrm{R}, \mathrm{ROH}$ and GLY stand for triglycerides, diglycerides, monoglycerides, ester (biodiesel), alcohol and glycerin, respectively (Rashid et al., 2011).

The major advantage of biodiesel is its biodegradability and non-toxicity. Biodiesel has an advantage over petroleum diesel fuel in the respect that it reduces soot or solid particles, carbon emissions and unburned hydrocarbons by $66.7 \%$, $46.7 \%$ and $45.2 \%$, respectively, as described by Schumacher et al. (2001). Carbon dioxide is produced during the burning of biodiesel and is used by plants in their photosynthesis, minimizing greenhouse gas emissions into the atmosphere (Agarwal and Das, 2001; Korbitz, 1999). Similarly, SOx emission is also reduced significantly (Yamane et al., 2001), it has good igniting capacity, i.e., its high methyl oleate content is characterized by lower emissions of $\mathrm{NO}$, hydrocarbons, $\mathrm{HCHO}$, $\mathrm{CH}_{3} \mathrm{CHO}, \mathrm{HCOOH}$, and lower carbon formation in burning since it contains oxygenates $(10 \%$ oxygen concentrations) as described by Maceiras et al. (2010). Petroleum diesel has a lower oxygen content and higher sulfur content than biodiesel making biodiesel a good alternative fuel. The use of biodiesel in engines has also resulted in a great reduction in the emission of particulate organic matter (POM), carbon monoxide (CO), polyaromatics, un-burned hydrocarbons, smoke and noise. In another study, Ruiz-Méndez et al. (2008) defined the analytical methods which are useful for obtaining information on the compounds present in used frying oils and to characterize the biodiesels obtained from them.

Maize (Zea mays L.) belongs to the Gramineae family and is a member of the Poaceae. It occupies and important place in the present cropping system of Pakistan. Its status is third after rice and wheat. Maize is grown primarily for grain and secondarily for fodder (Nadeem et al., 2008). Two regular maize crops per year are grown in most parts of the country, in spring (Jan-Feb) and in autumn (JulyAug). It is grown in almost all the provinces of the country, but Punjab and NWFP are the main areas of production. The soil and climatic conditions of Pakistan are ideal for maize production (Shah et al., 2001). It is highly associated with vigorous growth, a dark green color of leaves and stem, branching, leaf production and size enlargement. It is also gaining importance due to being a commercial/industrial crop, where a large number of products are being manufactured from its grain. Maize grain contains $72 \%, 10 \%, 5.8, \%, 4.8 \%$, $3.0 \%, 1.7 \%$ starch, protein, fiber, oil, sugar and ash, respectively (Chaudhary, 1983).

It is also a source of raw material for industry, where it is being extensively used for the preparation of starch, oil, syrup, dextrose, corn flakes, cosmetics, wax, alcohol and tanning material for the leather industry. Maize is grown in an area of 1.05 million hectares in Pakistan, producing 3.593 million tons of grain anually with an average grain yield of $3415 \mathrm{~kg} \mathrm{ha}^{-1}$ (GOP, 2010).

To our knowledge no comparative study on biodiesel produced from Maize oil has yet been reported. The present work was an attempt to produce biodiesel by utilizing Maize seed oil from Pakistan. A comparative study was also done for obtaining a high biodiesel yield with better quality. In addition, the fuel properties of the produced biodiesel were evaluated and compared with international standards.

\section{MATERIALS AND METHODS}

The crude Maize (Zea maize L.) oil was procured from Rafhan Maize Products Co. Ltd. Faisalabad, Pakistan. The standards of fatty acid (methyl and ethyl) esters were obtained from Sigma Chemical Company (St. Louis, MO, USA). The used chemicals and reagents were of analytical purity grade and acquired from Merck Chemical Company (Darmstadt, Germany).

\subsection{Pretreatment}

Before base catalyst transesterification, a pretreatment of the maize oil was done with methanol and ethanol using $\mathrm{H}_{2} \mathrm{SO}_{4}$ as a catalyst due to the high acid value of crude maize oil. For the pretreatment of maize oil a previously reported method was used (Moser and Vaughn, 2010). 


\subsection{Experimental conditions for transesterification}

The influence of reaction parameters (alcohol to oil ratio, type and concentration of catalyst and reaction time) on methanloylsis and ethanolysis for crude maize oil was evaluated through different sets of experiments under constant stirring (750 rpm). The catalysts (sodium hydroxide, potassium hydroxide, sodium methoxide and potassium methoxide) screening was done at $1.0 \%$ as reported in our previous study (Rashid and Anwar, 2008a). The concentration of the most effective catalysts originated in this work ranged from $0.25-1.50 \%$ (w/w of oil). The alcohol to maize oil ratio ranged from $3: 1-15: 1$. The reaction time ranged from $30-120 \mathrm{~min}$. The fixed temperature limit i.e. $65^{\circ} \mathrm{C}$ for methanolysis and $75^{\circ} \mathrm{C}$ for ethanolysis was selected, based on the boiling point of each alcohol.

\subsection{Transesterification of oil}

Transesterification was done in a glass reactor which consists of a round bottom flask, thermometer, sampling port, reflux condenser and hot plate under constant stirring provided by a magnetic stirrer (Rashid and Anwar, 2008b). The maize oil $(200 \mathrm{~g})$ was preheated to the preferred temperature before initiating the reaction mixture. For complete transesterification of the maize oil into the respective esters each experiment was conducted for $120 \mathrm{~min}$. After reaction completion, the reacted material was transferred to a separating funnel and kept in a state of equilibrium for complete separation of the two divergent phases. From the two clearly separated phases, the upper layer consisted of fatty esters, whereas the lower phase contained glycerol and other contaminants (unused alcohol, un-reacted catalysts, soaps derived during the reaction, some suspended esters and partial glycerides). The purified upper layer consisting of methyl and ethyl esters was collected by distilling off residual methanol and ethanol. The unreacted catalyst and glycerol were eliminated through successive washings with distilled water $\left(45^{\circ} \mathrm{C}\right)$. The residual water contents were dried with sodium sulfate followed by filtration (Rashid and Anwar, $2008 \mathrm{~b})$. The biodiesel yield (\%) was determined using the following formula;

$$
\begin{gathered}
\text { Biodiesel yield }(\mathrm{wt} \%)= \\
\text { grams of methyl/ethyl esters produced } \\
\text { grams of maize oil used in reaction }
\end{gathered} \times 100
$$

\subsection{Catalyst screening}

For screening the base catalysts $\left(\mathrm{NaOCH}_{3}\right.$, $\mathrm{KOCH}_{3}, \mathrm{NaOCH}_{2} \mathrm{CH}_{3}, \mathrm{KOCH}_{2} \mathrm{CH}_{3}, \mathrm{NaOH}$ and $\mathrm{KOH}$ ) were used separately by adding freshly prepared methanolic and ethanolic solutions of the respective catalysts to the maize oil. For methanolysis, the following operating conditions were chosen: $0.75 \%$ catalyst, 6:1 methanol to oil molar ratio, $720 \mathrm{rpm}$ rate of agitation, $65^{\circ} \mathrm{C}$ reaction temperature and for ethanolysis: $1.0 \%$ catalyst, $9: 1$ ethanol to oil molar ratio, $720 \mathrm{rpm}$ rate of agitation, $75^{\circ} \mathrm{C}$ reaction temperature.

\subsection{Analytical procedure}

The fatty acid profile of maize oil and its esters was determined using the previous experimental conditions of gas chromatography (GC) (Rashid et al., 2008b).

The FTIR-ATR spectrum of produced esters was recorded by inserting a droplet of the respective liquid between diamond composite FTIR-ATR sample holding plates. The sample holding plates were equipped with a load to spread the sample uniformly and tightly against the diamond surface. FTIR-ATR spectra were obtained by averaging 10 scans from 350 to $6000 \mathrm{~cm}^{-1}$ wavelengths at a resolution of $2 \mathrm{~cm}^{-1}$. A spectrum from the diamond composite plates is recorded as a background.

\subsection{Fuel properties of fatty acid esters/ Biodiesel}

The cetane number (ASTM D613), kinematics viscosity at $40^{\circ} \mathrm{C}$ (ASTM D445), oxidative stability (EN 14112), cloud point (ASTM D2500), pour point (ASTM D97), cold filter plugging point (ASTM D6371), flash point (ASTM D92), sulfur content (ASTM D4294), ash content (ASTM D874), acid value (ASTM D974), copper strip corrosion (ASTM D849), density (ASTM D5002), higher heating value (ASTM D4868), ester content (EN14103), methanol content (ASTM D4868), free glycerin (EN 14110) and total glycerin (ASTM D6584) were calculated.

\subsection{Statistical analysis}

Three samples of maize oil were acquired. Each sample was analyzed individually in triplicate and data are reported as mean $(n=3 \times 3) \pm S D$ $(n=3 \times 3)$.

\section{RESULTS AND DISCUSSIONS}

\subsection{Crude maize oil}

Prior to base catalyzed transesterification, characterization of the maize oil was also done. The maize oil had an acid value of $2.90 \mathrm{mg} \mathrm{KOH} / \mathrm{g}$, which needed pre-treatment and then reduced the acid value to less than $1 \%$ before the base catalyzed reaction. The iodine value of the parent oil was $117.25 \mathrm{~g} \mathrm{I}_{2} / 100 \mathrm{~g}$. The peroxide value of maize oil was $3.20 \mathrm{~m} \mathrm{eq} / \mathrm{kg}$ and the saponification value was $117.25 \mathrm{mg} \mathrm{KOH} / \mathrm{g}$. The water content of maize oil was 901 ppm. 


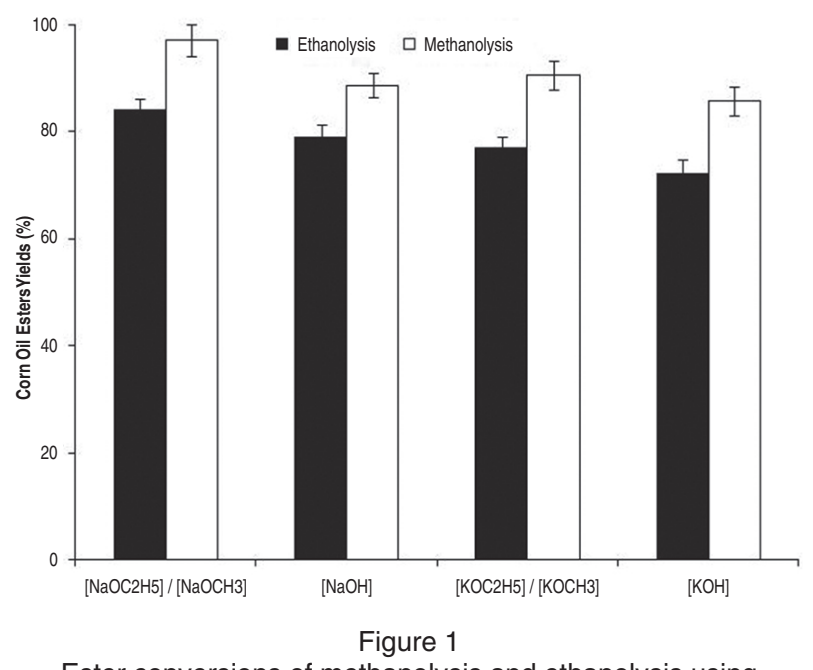

Ester conversions of methanolysis and ethanolysis using different catalysts.

\subsection{Screening of catalyst for transesterification reaction}

To carry out the catalytic screening of different basic catalysts for the corn oil methanolysis and ethanolysis reactions, the ester conversions have been calculated from the produced ester yields and are presented in Figure 1. The reaction conditions $(0.75 \%$ catalyst, $6: 1$ methanol to oil molar ratio, 720 rpm rate of agitation, $65^{\circ} \mathrm{C}$ temperature for methanolysis and $1.00 \%$ catalyst, 9:1 ethanol to oil molar ratio, $720 \mathrm{rpm}$ rate of agitation, $75^{\circ} \mathrm{C}$ reaction temperature for ethanolysis were employed for comparisons among the catalysts. In this experiment, four different catalysts $\left(\mathrm{NaOCH}_{3}, \mathrm{KOCH}_{3}\right.$, $\mathrm{NaOCH}_{2} \mathrm{CH}_{3}, \mathrm{KOCH}_{2} \mathrm{CH}_{3}, \mathrm{NaOH}$ and $\mathrm{KOH}$ ) for methanolysis and ethnolysis were used. As can be seen in Figure 1, the optimum yields for MOMEs and MOEEs were achieved with $\mathrm{NaOCH}_{3}$ and $\mathrm{NaOCH}_{2} \mathrm{CH}_{3}$ catalysts under the specified conditions. Among the tested catalysts, the oxides $\left(\mathrm{NaOCH}_{3}\right.$, $\mathrm{NaOCH}_{2} \mathrm{CH}_{3}, \mathrm{KOCH}_{2} \mathrm{CH}_{3}, \mathrm{KOCH}_{3}$ ) exhibited higher conversions of methyl and ethyl esters than the corresponding hydroxides $(\mathrm{NaOH}, \mathrm{KOH})$, obtained in the work of Anwar et al. (2010). These outcomes were expected because hydroxides form water during the reaction and emulsify the product, causing the yield of methyl and ethyl esters to be low. It was found that the most active catalysts were $\mathrm{NaOCH}_{3}$ for methanolysis and $\mathrm{NaOCH}_{2} \mathrm{CH}_{3}$ for ethanolysis under the specified conditions, achieving 97 and $85 \%$ methyl and ethyl ester conversions, respectively.

\subsection{Influence of catalyst concentration for transesterification reaction}

The yield of biodiesel can be affected by the amount of catalyst used during the methanolysis and ethanolysis of corn oil. In the present study, the catalyst concentration ranged from $0.25-1.50 \%$ for both methanolysis and ethanolysis reactions which are depicted in Figure 2 and 3, respectively. Methanolysis was carried out using an $\mathrm{NaOCH}_{3}$

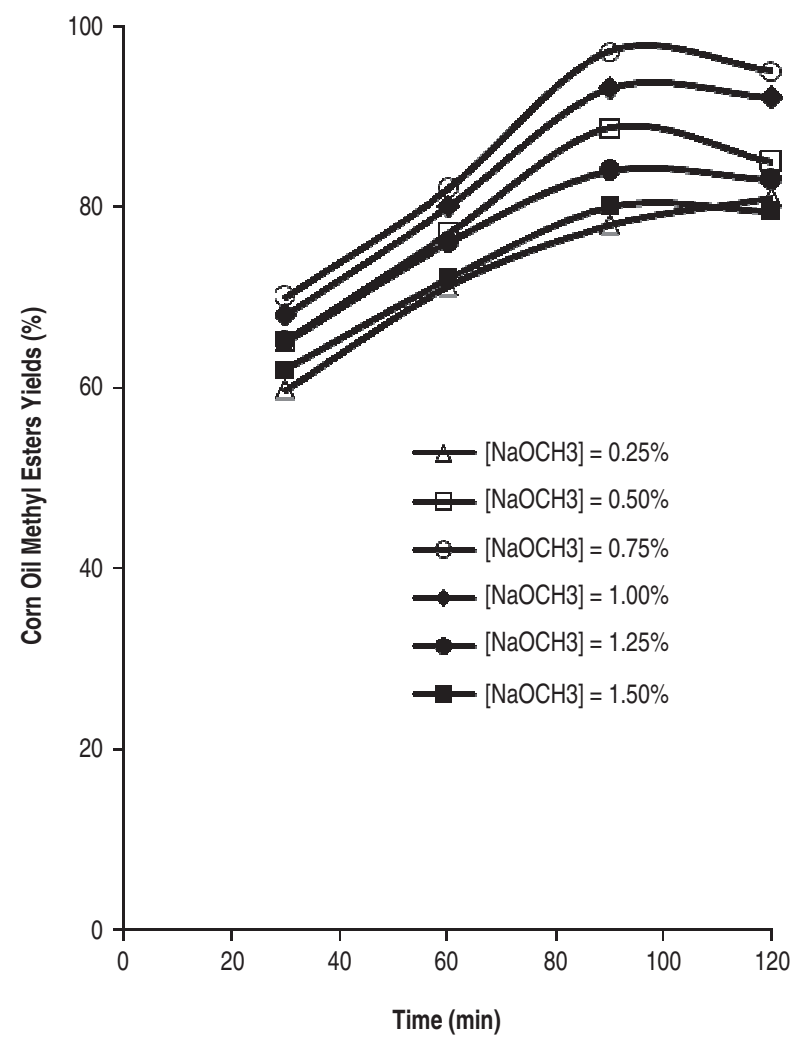

Figure 2

Influence of catalyst concentration on methanolysis.

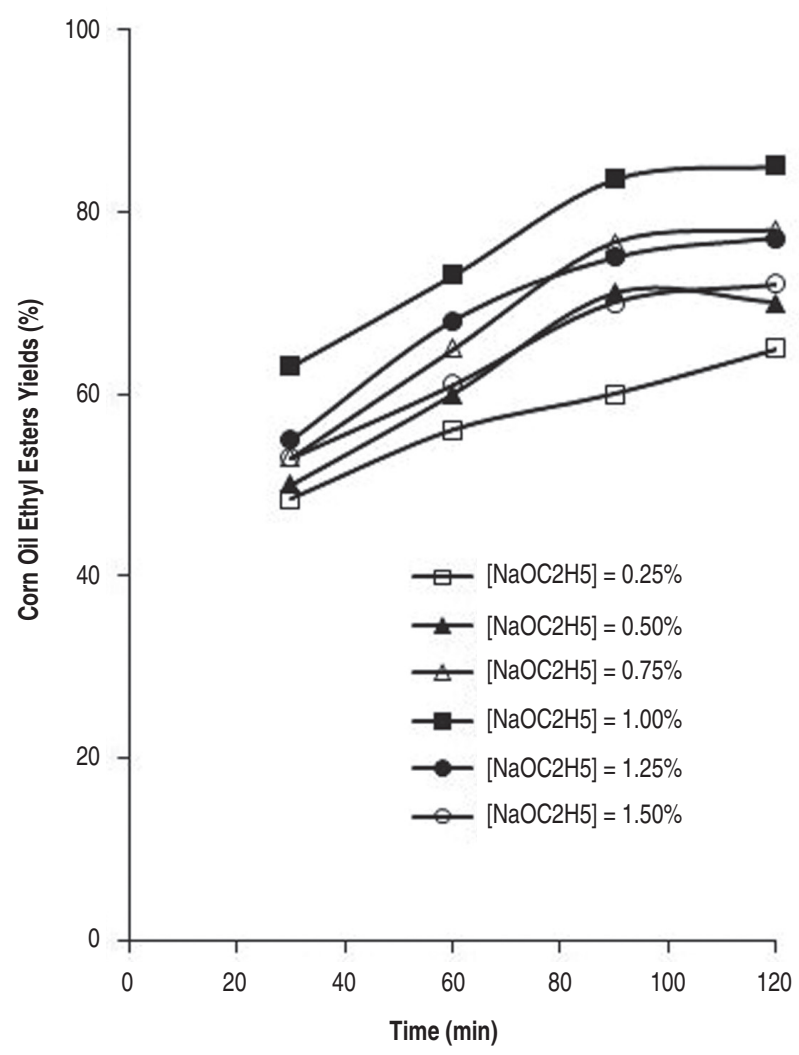

Figure 3

Influence of catalyst concentration on ethanolysis. 
catalyst, 6:1 methanol to oil molar ratio, $720 \mathrm{rpm}$ rate of agitation and $65^{\circ} \mathrm{C}$ reaction temperature. The optimum yield of biodiesel $(97.2 \%)$ in the case of methanolysis was achieved at $0.75 \%$ concentration of catalyst (Figure 2). On the other hand, the ethanolysis process was carried out with a $\mathrm{NaOCH}_{2} \mathrm{CH}_{3}$ catalyst, 9:1 methanol to oil molar ratio, $720 \mathrm{rpm}$ rate of agitation and $75^{\circ} \mathrm{C}$ reaction temperature. Figure 3 indicates the biodiesel yield using $\mathrm{NaOC}_{2} \mathrm{H}_{5}$ catalysts with different concentrations. It can be seen (Figure 3 ) that the maximum $(85 \%)$ biodiesel yield in ethanolysis was obtained at $1.0 \%$ concentration of $\mathrm{NaOCH}_{2} \mathrm{CH}_{3}$. In the case of methanolysis the maximum yield was obtained after $90 \mathrm{~min}$ but for ethanolysis the optimum yield was obtained at $120 \mathrm{~min}$. Meneghetti et al., (2006) also reported that methanolysis is much faster than ethanolysis.

\subsection{Influence of alcohol to oil molar ration for the transesterification reaction}

In the current analysis, the effect of the alcohol to oil proportion on the ester yields for methanolysis was studied by varying the alcohol to oil molar ratio from $3: 1$ to $15: 1$, while maintaining the temperature and sodium methoxide concentration constant at $60^{\circ} \mathrm{C}$ and $0.75 \%$ and for ethanolysis the catalyst was the same but at $75^{\circ} \mathrm{C}$ (at $2 \mathrm{~h}$ reaction time). Five molar ratios for alcohol to oil were examined (3:1, 6:1, 9:1, 12:1 and 15:1). The methanol to oil ratio 6:1, as depicted in Figure 4, clearly exhibited higher biodiesel yield $(97.2 \%)$, whereas, $85 \%$

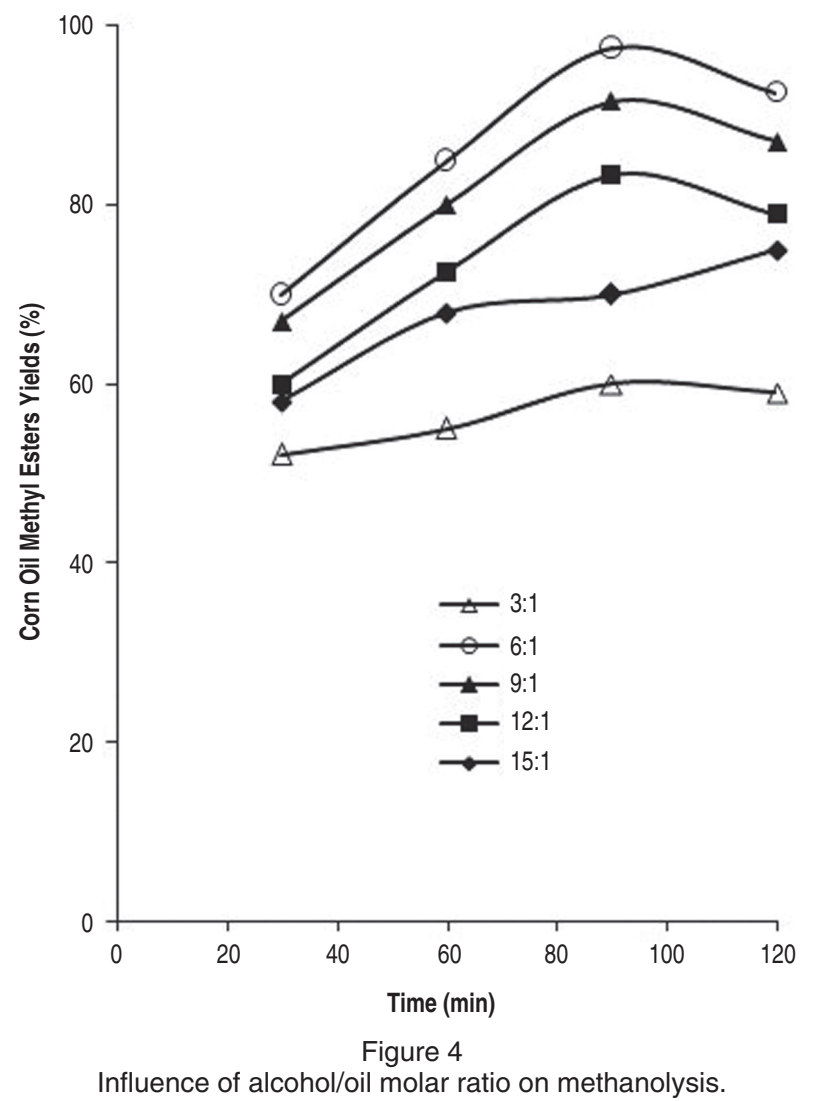

optimum biodiesel yield was observed at 9:1 (Figure 5) for ethanolysis. When the methanol to used oil molar ratio was increased from 9:1 to 15:1, the methyl ester concentration decreased (Figure 5) but for ethanolysis the yield decreased after 9:1 (Figure 5). The literature revealed that above the molar ratio of $6: 1$, further methanol addition had no considerable effect on ester formation but rather complicated ester recovery and increased the cost of the process (Goff et al., 2004). In the case of the methanol to oil molar ratio $>6: 1$, a dilution effect is likely the cause while for the molar ratio $<6: 1$, insufficient mixing of the reactants in the biphasic transesterification reaction system might lead to lower ester yields. These results are comparable with those of Meher et al. (2006) and Usta (2006) who obtained the best ester yields with a molar relation of $6: 1$ during the methanolysis of Pongamia pinnata and tobacco seed oil, respectively.

\subsection{Quality of biodiesel analysis}

In this study, the fatty acid (FA) composition of maize oil biodiesel was determined using gas chromatography. The experimental results are summarized in Table 1, which shows the percentage content of the individual fatty acids. The content of total saturated fatty acids (SFA) and unsaturated fatty acids (USFA); palmitic $\left(\mathrm{C}_{16: 0}\right)$, stearic $\left(C_{18: 0}\right)$, oleic acid $\left(C_{18: 1}\right)$, linoleic $\left(C_{18: 2}\right)$, linolenic $\left(\mathrm{C}_{18: 3}\right)$ and arachadic acids were in the range of $9.98,1.80,36.00,54.89,0.98$ and $0.30 \%$, respectively. The content of total saturated fatty

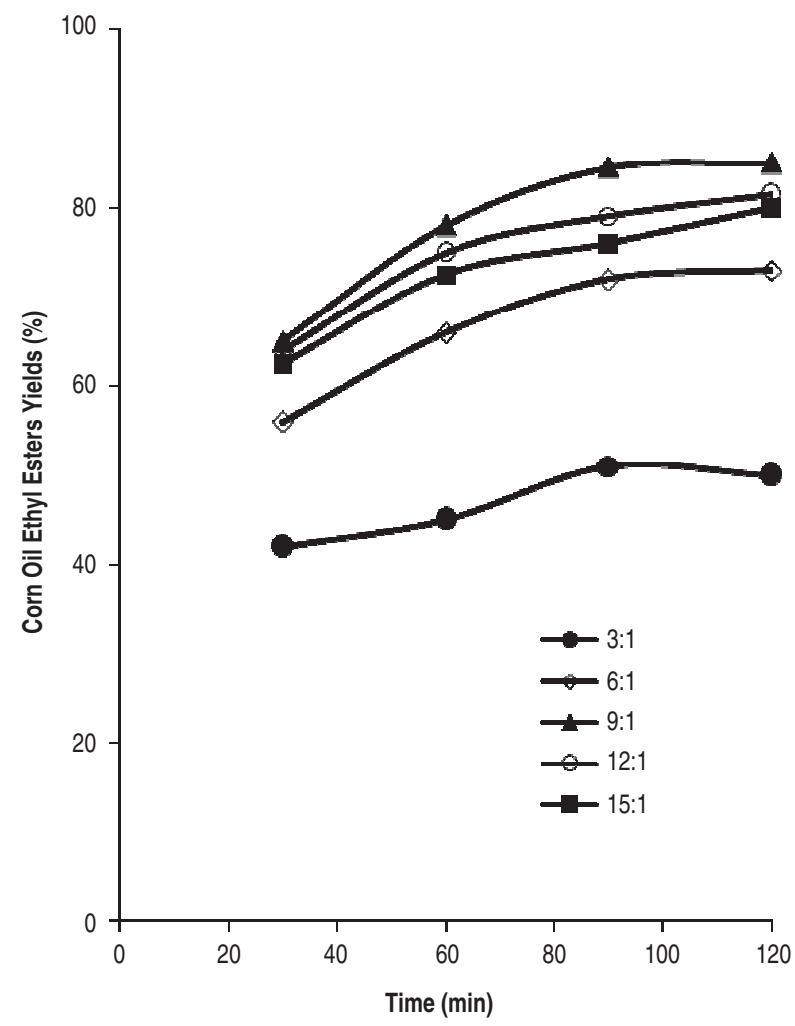

Figure 5

Influence of alcohol/oil molar ratio on ethanolysis. 
Table 1

Fatty acid (FA) composition (g/100 g of FA) of maize oil esters

\begin{tabular}{lc}
\hline FAMEs (\%) & Maize oil esters \\
\hline Palmitic (C16:0) & $9.98 \pm 0.51$ \\
Stearic (C18:0) & $1.80 \pm 0.02$ \\
Oleic (C18:1) & $36.00 \pm 1.73$ \\
Linoleic (C18:2) & $50.89 \pm 2.06$ \\
Linolenic (C18:3) & $0.98 \pm 0.01$ \\
Arachidic (C20:0) & $0.30 \pm 0.02$ \\
$\Sigma_{\text {SFA }}$ & 12.08 \\
$\Sigma_{\text {UFA }}$ & 87.87 \\
\hline
\end{tabular}

Values are mean \pm SD analyzed individually in triplicate. $\Sigma_{\mathrm{SFA}}=$ Total saturated fatty acids; $\Sigma_{\mathrm{UFA}}=$ Total unsaturated fatty acids.

acids (SFA); palmitic $\left(\mathrm{C}_{16: 0}\right)$, stearic $\left(\mathrm{C}_{18: 0}\right)$ and arachidic $\left(\mathrm{C}_{20: 0}\right)$ acid in the produced biodiesel were $12.08 \%$. Whereas the investigated maize oil esters were found to contain a high level of unsaturated fatty acids (UFA) i.e. $87.87 \%$. The highest content of linoleic acid $\left(\mathrm{C}_{18: 2}\right)$ was found up to a level of $50.89 \%$ in the produced biodiesel. The qualities of the produced biodiesel were authenticated by observing small differences in the location of the bands of the carbonyls of the produced esters in relation to the maize oil. FT-IR spectra of MOMEs and MOEEs are depicted in Figure 6 and 7. FTIR spectrums would indicate that the reaction has attained conversion to a product that also conforms to standards. On the basis of the above results it can be assumed that the FT-IR results are accurate, even if not all potential contaminants have been fully analyzed. The most important carbonyl group absorption peak $(\mathrm{C}=\mathrm{O}$ stretch) was observed at 1741-1743 $\mathrm{cm}^{-1}$, demonstrating the ester peak (Silverstein and Webster, 1998). The band observed in the produced biodiesel at $1169 \mathrm{~cm}^{-1}$ is attributed to methyl groups and $1160 \mathrm{~cm}^{-1}$ is due to ethyl ester groups (Roeges 1994). The band corresponding to the $\mathrm{vC}(=\mathrm{O})-\mathrm{O}$ vibration shows a peak at 1244 and $1236 \mathrm{~cm}^{-1}$ in biodiesel and is one of the confirmations of the conversion of maize oil to respective methyl and ethyl esters. The major change i.e. methoxycarbonyl group in biodiesel with respect to maize oil was also observed mainly at $2923 \mathrm{~cm}^{-1}$.

Table 2 depicts the fuel properties of optimized produced biodiesels (methyl and ethyl esters), which were determined according to biodiesel standards (ASTM D6751 and EN 14214). The cetane number of produced esters was determined using the Ignition Quality Tester (IQT ${ }^{\mathrm{TM}}$ ) method as reported by Knothe et al. (2003). The maximum cetane number was detected in maize oil methyl esters (MOMEs) (56), whereas a cetane number of 54 was observed for maize oil methyl esters (MOEEs). The better ignitability of the biodiesel fuel depends on a higher value of cetane number along with a reduction in NOx emissions as well (Rashid et al., 2008). All the produced biodiesel fulfill the minimum cetane number requirements for both American (ASTM D6751) and European (EN 14214) biodiesel standards, which are 47 and 51, respectively. The kinematic viscosity is related to the presence of triglycerides, diglycerides and monoglycerides in the

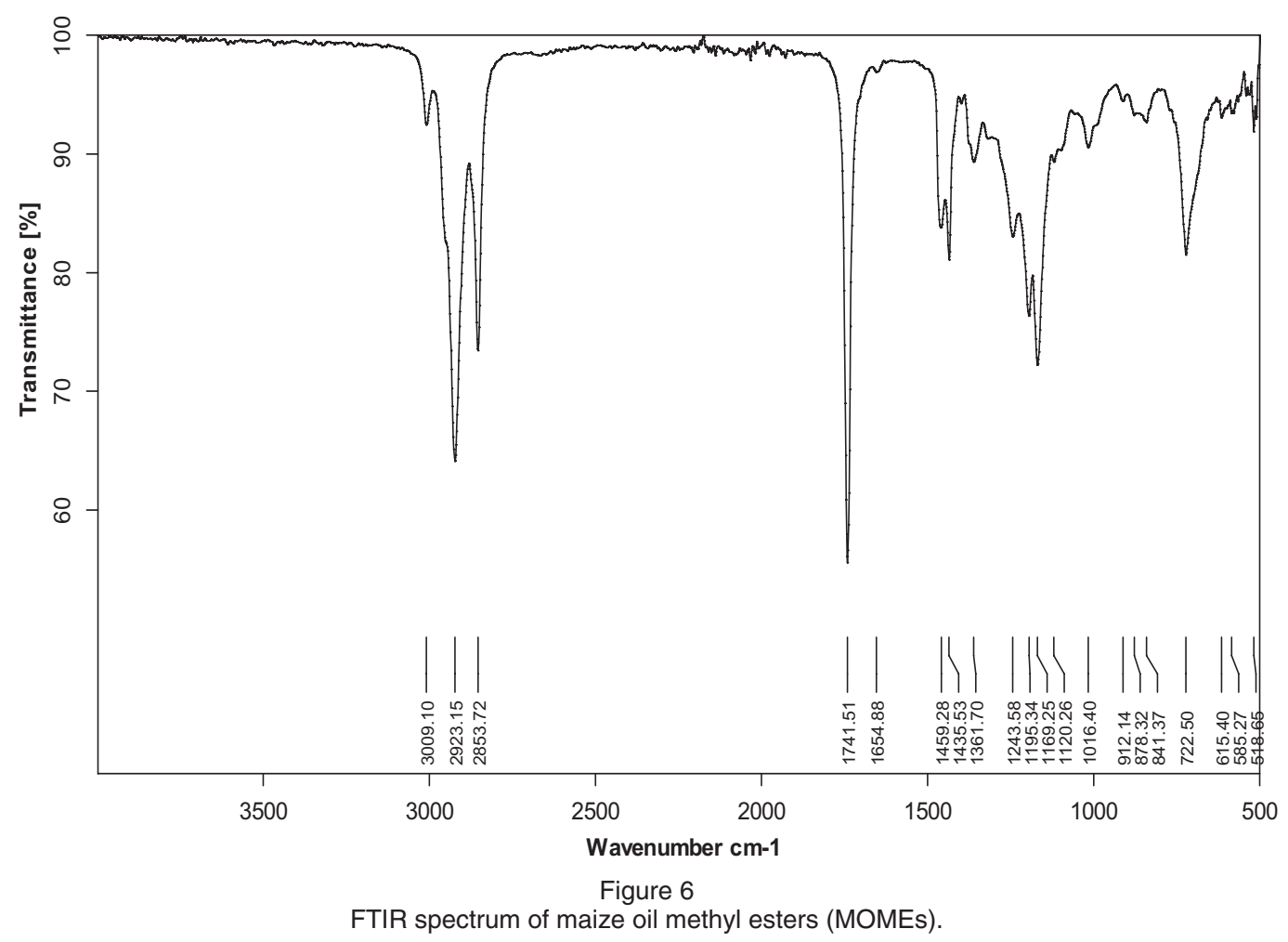




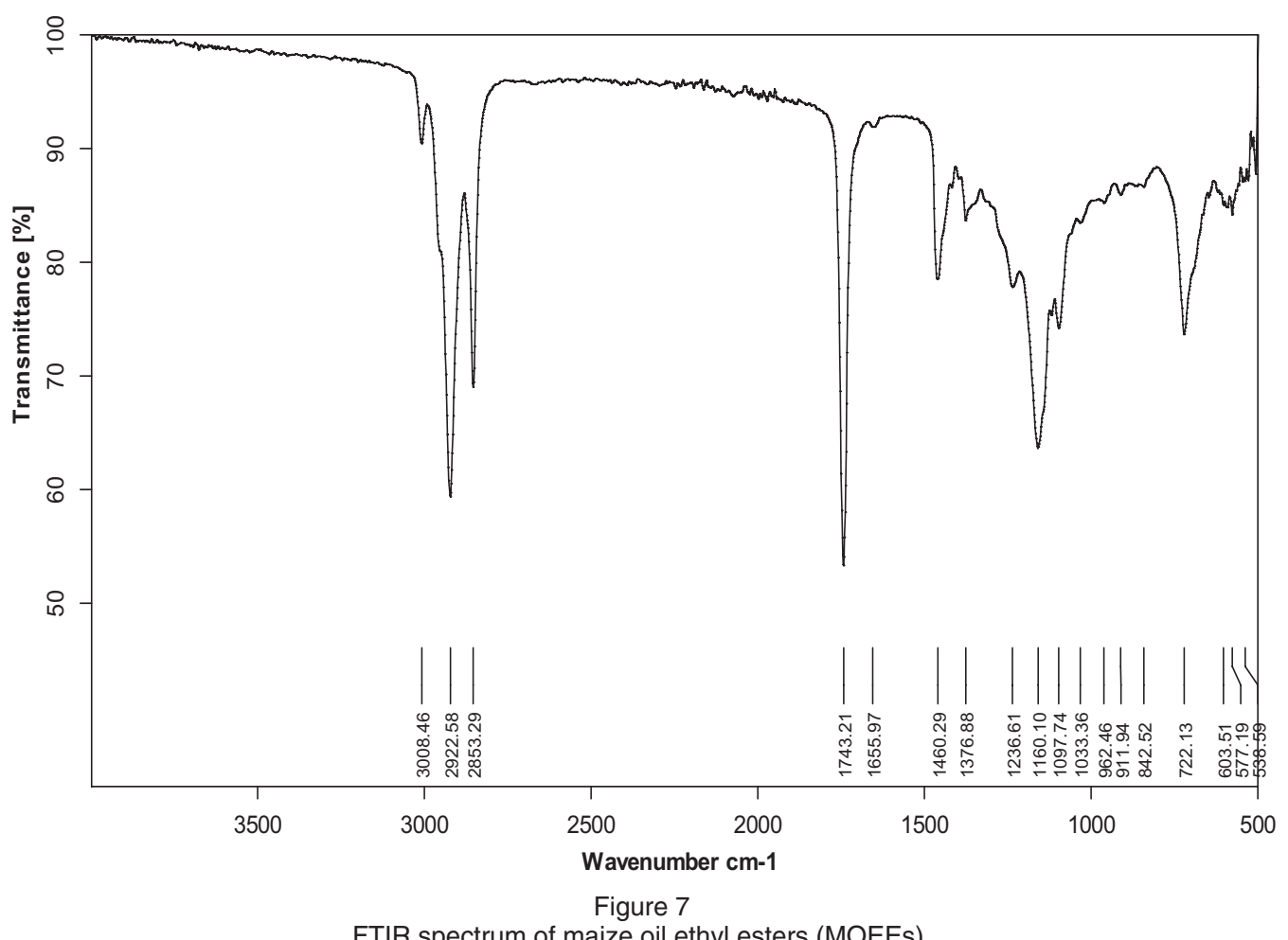

biodiesel. In the optimized biodiesel tested samples, the maximum kinematic viscosity $\left(\mathrm{mm}^{2} \mathrm{~s}^{-1}\right)$ was determined in MOEEs (4.48) but MOMEs showed 3.83. As compared to biodiesel standards both esters were within the range of ASTM kinematic viscosity $\left(40^{\circ} \mathrm{C}, 5.18 \mathrm{~mm}^{2} \mathrm{~s}^{-1}\right)$ standard as well as the EN $14214\left(3.5-5.0 \mathrm{~mm}^{2} \mathrm{~s}^{-1}\right)$ specification. The Rancimat method EN 14112 was used to evaluate the oxidative stability of esters. A Rancimat induction time for MOMEs and MOEEs obtained 2.03 and

Table 2

Properties of maize oil esters in comparison to biodiesel standards

\begin{tabular}{|c|c|c|c|c|}
\hline Fuel property & MOMEs & MOEEs & ASTM D6751 & EN 14214 \\
\hline Cetane number & $56.00 \pm 1.54$ & $54.00 \pm 1.70$ & $47 \mathrm{~min}$ & $51 \mathrm{~min}$ \\
\hline Kinematic viscosity at $40^{\circ} \mathrm{C}\left(\mathrm{mm}^{2} \mathrm{~s}^{-1}\right)$ & $3.83 \pm 0.05$ & $4.48 \pm 0.06$ & $1.9-6.0$ & $3.5-5.0$ \\
\hline Oxidative stability (h) & $2.03 \pm 0.02$ & $1.97 \pm 0.03$ & $3 \mathrm{~min}$ & $6 \min$ \\
\hline Cloud point $\left({ }^{\circ} \mathrm{C}\right)$ & $-2.00 \pm 0.12$ & $-2.00 \pm 0.10$ & Report & $-{ }^{\mathrm{a})}$ \\
\hline Pour point $\left({ }^{\circ} \mathrm{C}\right)$ & $-4.00 \pm 0.15$ & $-12.00 \pm 0.16$ & - b) & $-{ }^{a)}$ \\
\hline Cold filter plugging point $\left({ }^{\circ} \mathrm{C}\right)$ & $-1.00 \pm 0.08$ & $-3.00 \pm 0.11$ & - b) & $--^{\text {a) }}$ \\
\hline Flash point $\left({ }^{\circ} \mathrm{C}\right)$ & $164 \pm 4.84$ & $160 \pm 4.99$ & $93 \mathrm{~min}$ & $120 \mathrm{~min}$ \\
\hline Sulfur content (\%) & $0.012 \pm 0.002$ & $0.011 \pm 0.001$ & $0.05 \max$ & - \\
\hline Ash content (\%) & $0.016 \pm 0.002$ & $0.017 \pm 0.002$ & $0.02 \max$ & $0.02 \max$ \\
\hline Acid value $\left(\mathrm{mg} \mathrm{KOH} \mathrm{g}^{-1}\right)$ & $0.18 \pm 0.09$ & $0.45 \pm 0.03$ & $0.50 \max$ & $0.50 \max$ \\
\hline Copper strip corrosion $\left(50^{\circ} \mathrm{C}, 3 \mathrm{~h}\right)$ & $1 \mathrm{a}$ & $1 a$ & No. 3 max & No. $1 \mathrm{~min}$ \\
\hline Density $\left(25^{\circ} \mathrm{C}\right), \mathrm{kg} \mathrm{m}^{-3}$ & $886 \pm 14.7$ & $912 \pm 17.1$ & - & - \\
\hline Higher heating value $\left(\mathrm{MJ} \mathrm{kg}^{-1}\right)$ & $45.35 \pm 0.96$ & $43.05 \pm 1.00$ & - & - \\
\hline Ester content (\%) & $97.02 \pm 2.68$ & $87.07 \pm 3.20$ & & $96.5 \%\left(\mathrm{~mol} \mathrm{~mol}^{-1}\right), \mathrm{min}$ \\
\hline Methanol content (\%) & $0.180 \pm 0.004$ & $0.180 \pm 0.003$ & - & $0.2 \max$ \\
\hline Free glycerin (\%) & $0.013 \pm 0.001$ & $0.016 \pm 0.002$ & $0.020 \max$ & $0.020 \max$ \\
\hline Total glycerin (\%) & $0.235 \pm 0.018$ & $0.228 \pm 0.014$ & $0.240 \max$ & $0.250 \max$ \\
\hline
\end{tabular}

Values are mean \pm SD. Maize Oil Methyl Esters (MOMEs); Maize Oil Ethyl Esters (MOEEs).

a) Not specified. EN 14214 uses time and location-dependent values for the cold filter plugging point (CFPP)

b) Not specified. 
$1.97 \mathrm{~h}$. The produced ester values are lower than the minimum times with reference to ASTM D 6751 $(\geq 3 \mathrm{~h})$ and EN $14214(6 \mathrm{~h})$. Due to the loss of antioxidants during methanolysis/ethanolysis, the rancimat induction time was reduced in comparison to base oil (Rashid et al., 2008). The acquired cloud point $(\mathrm{CP})$ for MOMEs and MOEEs were -2 and $-2^{\circ} \mathrm{C}$, while pour point (PP) values were -4 and $-12^{\circ} \mathrm{C}$ for MOMEs and MOEEs. The cold-filter plugging point (CFPP) was found to be $-1^{\circ} \mathrm{C}$ in MOMEs, followed by MOEEs $\left(-3^{\circ} \mathrm{C}\right)$ and must be sufficiently low because the varied climatic conditions have an impact on the cold flow properties of biodiesel. The low temperature properties of a biodiesel fuel can be enhanced through the use of additives and/or esters other than methyl or through variation in the fatty acid profile (Imahara et al., 2006). In the present study, the flash point determined for MOMEs (FP $164^{\circ} \mathrm{C}$ ), and MOEEs (FP $160^{\circ} \mathrm{C}$ ) are within the prescribed limits according to American and European biodiesel standards and is also higher than that of No.2 diesel fuel. A higher value of FP decreases the risk of fire (Rashid and Anwar, 2008b). The other properties i.e. sulfur content, ash content, acid value, copper strip corrosion, density and higher heating values for both MOMEs and MOEEs were within the standards (Table 1). Finally, a GC analysis indicated that optimized produced esters were within ASTM D 6751 specifications for free and total glycerol set in the biodiesel standards (0.02 for free glycerol and $0.24 \%$ and $0.25 \%$ for total glycerol in the ASTM and EN standards, respectively).

\section{CONCLUSIONS}

The most favorable conditions elucidated for the methanolysis of maize oil were established as: 6:1 molar ratio of maize oil to methanol, $0.75 \%$ sodium methoxide catalyst (wt\%), and 90 min reaction time. Alternatively, 9:1 ethanol to oil molar ratio (mol/ $\mathrm{mol}$ ), $1.00 \%$ sodium ethoxide concentration (wt\%) and $120 \mathrm{~min}$ reaction time for the ethanolysis of maize oil were determined. The results of this study showed that using alkaline catalysts for biodiesel production with maize oil could be a potential way, and as such, provided useful information for the conditions optimization of other base catalyst processes. The fuel properties of the produced esters (MOMEs and MOEEs) were determined to be within the prescribed specifications (ASTM D6751 and EN14214).

\section{ACKNOWLEDGEMENTS}

The data presented here is part of research work of Bachelor Theses at GC University, Faisalabad. The authors are thankful to Dr. Farooq Anwar (Department of Chemistry, University of Agriculture, Faisalabad) and Mr. Muhammad Aamir (Attock Refinery Limited, Rawalpindi) for their assistance.

\section{REFERENCES}

Agarwal AK, Das LM. 2001. Biodiesel development and characterization for use as a fuel in compression ignition engine. J. Eng. Gas Turb. Power. 123, 440-447.

Anwar F, Rashid U, Ashraf M, Nadeem M. 2010. Okra (Hibiscus esculentus) seed oil for biodiesel production. Appl. Energy. 87, 779-785.

American Standards for Testing of Materials (ASTM) D 130, D 2500, D 287, D 4294, D 4868, D 6079, D 6371, D 6751, D 7042, D 874, D 92, D 93, D 95, D 97, D 974. St. Joseph, MI, ASAE; 2003.

Cerveró JM, Coca J, Luque S. 2008. Production of biodiesel from vegetable oils. Grasas Aceites 59, 76-83.

Chaudhary AR. 1983. Maize in Pakistan. Punjab Agri. Coordination Board, University of Agriculture, Faisalabad.

Encinar JM, González JF, Rodriguez-Reinares A. 2005. Biodiesel from used frying oil. Variables affecting the yields and characteristics of the biodiesel. Ind. Eng. Chem. Res. 44, 5491-5499.

European Committee for Standardization, EN 14112, Fat and oil derivatives. Fatty acid methyl esters (FAMEs). Determination of oxidation stability (accelerated oxidation test). Brussels, Belgium, 2003.

Goff MJ, Bauer NS, Lopes S, Sutterlin WR, Suppes GJ. 2004. Acid-catalyzed alcoholysis of soybean oil. J. Am. Oil Chem. Soc. 81, 415-420.

Government of Pakistan (GOP). 2010. Agricultural Statistics of Pakistan 2008-2009. Ministry of Food Agriculture and Livestock (MINFAL). Food Agriculture and Livestock Division, Islamabad, Pakistan.

Imahara H, Minami E, Saka S. 2006. Thermodynamic study on cloud point of biodiesel with its fatty acid composition. Fuel 85, 1666-1670.

Knothe G, Matheaus AC, Ryan TW. 2003. Cetane numbers of branched and straight-chain fatty esters determined in an ignition quality tester. Fuel 82, 971-975.

Korbitz W. 1999. Biodiesel production in Europe and North America, an encouraging prospect. Renew. Energ. 16, 1078-1083.

Maceiras R, Rivero JJ, Cancela MA, Urrejola S, Sanchez A. 2010. Development and modeling of production of biodiesel from sunflower oil. Chem. Technol. Fuels Oils 46, 154-159.

Moser BR, Vaughn SF. 2010. Evaluation of alkyl esters from Camelina sativa oil biodiesel and as blend components in ultra low-sulfur diesel fuel. Bioresource Technol. 101, 646-653.

Meher LC, Sagar DV, Naik SN. 2006. Technical aspects of biodiesel production by transesterification-a review. Renew. Sustain. Energ. Rev.10, 248-268.

Nadeem MA, Ahmad R, Khalid M, Naveed M, Tanveer A, Ahmad JN. 2008. Growth and yield response of autumn planted Maize (Zea mays L.) and its weeds to reduced doses of herbicide application in combination with urea. Pak. J. Bot. 40, 667-676.

Rashid U, Anwar F, Moser BR, Knothe G. 2008. Moringa oleifera oil: A possible source of biodiesel, Bioresource Technol. 99, 8175-8179.

Rashid U, Anwar F. 2008a. Production of biodiesel through base-catalyzed transesterification of safflower oil using an optimized protocol. Energy Fuels 22, 1306-1312.

Rashid U, Anwar F. 2008b. Production of biodiesel through optimized alkaline-catalyzed transesterification of rapeseed oil. Fuel 86, 265-271. 
Rashid U, Rahman HA, Hussain I, Ibrahim M, Haider MS. 2011. Muskmelon (Cucumis melo) seed oil: A potential non-food oil source for biodiesel production. Energy, 36, 5632-5639.

Rashid U, Anwar F, Arif M. 2009. Optimization of base catalytic methanolysis of sunflower (Helianthus annuus) seed oil for biodiesel production by using response surface methodology. Ind. Eng. Chem. Res. 48, 1719-1729.

Rivera I, Villanueva G, Sandoval G. 2009. Biodiesel production from animal grease wastes by enzymatic catalysis, Grasas Aceites 60, 468-474.

Roeges NPG. 1994. A guide to complete interpretation of infrared spectra of organic structures. John Wiley \& Sons, Chicester.

Ruiz-Mendez MV, Marimesat S, Liotta A. 2008. Analysis of used frying fats for the production of biodiesel. Grasas Aceites 59, 45-50.
Schumacher LG, Marshall W, Krahk J. 2001. Biodiesel emissions data from series 60 DDC engines. Trans. ASAE 44, 1465-1468.

Shah SH, Bashir M, Zamir MSI. 2001. Quantitative and qualitative response of maize (Zea mays L.) to EM Bioaab and fertilizers. Intl. J. Agric. Bio. 3, 105-107.

Silverstein RM, Webster FX. 1998. Spectrometric identification of organic compounds, $6^{\text {th }}$ ed John Willey \& Sons, New York.

Usta N. 2005. Use of tobacco seed oil methyl ester in a turbocharged indirect injection diesel engine. Biomass Bioenerg. 28, 77-86.

Yamane K, Ueta A, Shimamoto Y. 2001. Proc. 5th Int. Symp. on Diagnostics and Modeling of Combustion in Internal Combustion Engines (COMODIA 2001), Nagoya, pp. 402-409.

Recibido: 7/6/11 Aceptado: 22/8/11 